\title{
CAMPUR KODE PADA AKUN INSTAGRAM @DEMAKHARIINI (KAJIAN SOIOLINGUISTIK)
}

\author{
Dwi Septiani ${ }^{1}$, Arina Manasikana ${ }^{2}$ \\ 1,2 Program Studi Sastra Indonesia, Fakultas Sastra, Universitas Pamulang, Banten \\ E-mail: ${ }^{1}$ (dosen01401@ unpam.ac.id), ${ }^{2}$ (rinaaarinamanasikana@ gmail.com)
}

\begin{abstract}
Abstrak
Penelitian ini bertujuan untuk mendeskripsikan jenis-jenis dan bentuk-bentuk campur kode pada akun Instagram @demakhariini yang jenis penelitiannya adalah deskriptif kualitatif. Data dalam penelitian ini berjumlah 88 data yang mengandung unsur campur kode di dalamnya. Data-data tersebut diperoleh dari caption atau keterangan pada unggahan foto dan video di akun Instagram @ demakhariini. Pada penelitian ini ditemukan tiga jenis campur kode, yaitu jenis campur kode ke dalam, jenis campur kode ke luar dan jenis campur kode campuran. Hasil dari penelitian ini, jenis campur kode dominan adalah jenis campur kode ke luar, yaitu berjumlah 51 data atau 58\%, sedangkan jenis campur kode campur kode ke dalam berjumlah 21 data atau 24\%, dan jenis campur kode campuran berjumlah 16 data atau 18\%.
\end{abstract}

Kata kunci: Sosiolinguistik, campur kode, Instagram, @demakharini

\section{A. PENDAhUluan}

Hubungan manusia dan bahasa sangat erat kaitannya dan tidak dapat dipisahkan. Bahasa menjadi hal yang paling penting untuk berkomunikasi, untuk menyampaikan ide pikiran atau informasi seseorang kepada orang lain. Segala aktivitas hidup manusia tidak lepas dari berbahasa, karena itulah menandakan bahwa bahasa memiliki peranan penting bagi kehidupan manusia dan tidak dapat diragukan lagi.

Dalam Kamus Besar Bahasa Indonesia (KBBI) Edisi V luring, bahasa adalah sistem lambang bunyi yang bersifat arbriter (manasuka), digunakan oleh anggota suatu masyarakat untuk bekerja sama, berinteraksi, dan juga untuk mengidentifikasi diri. Dalam masyarakat, biasanya dikenal dengan bahasa baku dan bahasa tidak baku. Bahasa baku digunakan untuk acara-acara formal, seperti pada forum diskusi, presentasi, pidato dan sebagainya. Sedangkan bahasa tidak baku digunakan pada situasi yang lebih santai.

Kridalaksana (dalam Aslinda dan Syahfyahya, 2014:1) menyatakan bahwa bahasa adalah sistem lambang bunyi yang arbiter yang digunakan oleh suatu kelompok 
masyarakat untuk berkomunikasi dan mengidentifikasi diri. Pernyataan ini seperti yang ada di dalam KBBI. Berdasarkan pengertian tersebut, dapat disimpulkan bahwa bahasa merupakan sarana untuk berkomunikasi dan berinteraksi yang memiliki sistem sendiri dan hasil konvensi masyarakat bahasa tertentu.

Di Indonesia ada tiga bahasa yang dikenal oleh masyarakat, yaitu bahasa Indonesia atau bahasa nasional, bahasa daerah dan bahasa asing, seperti bahasa Inggris, bahasa Arab, dan sebagainya. Keberagaman suku, budaya, dan bahasa yang ada di Indonesia, menjadikan di setiap daerahnya terdapat bahasa daerah. Hal tersebut mejadi kebiasaan masyarakat Indonesia menyisipkan unsur bahasa daerah ketika menggunakan bahasa Indonesia atau menggunakan dua bahasa dalam komunikasi.

Era globalisasi yang menjangkau Indonesia dalam proses masuknya lingkup dunia, menuntut masyarakat untuk tidak terbatas dalam menggunakan bahasa. Mulanya masyarakat yang hanya menggunakan dan memahami bahasa nasional dan bahasa daerah, tetapi kini juga mulai menggunakan bahasa asing, seperti bahasa Inggris dan bahasa Arab untuk sebagian masyarakat tertentu, karena tuntutan pendidikan maupun pekerjaan. Hal tersebut yang menyebabkan saling mempengaruhi antar bahasa dan akhirnya terjadi kontak bahasa.

Kemudian di kota-kota besar, faktor mobilitas penduduk yang tinggi menyebabkan masyarakat multilingual. Karena hal tersebut, masyarakat menjadi campur kode, alih kode interferensi, dan integrasi dalam berbahasa. Hal ini yang menjadi kekhawatiran, jika suatu saat kosakata bahasa Indonesia akan hilang atau menyerap bahasa asing, yang di akibatkan karena seringnya menggunakan kosakata bahasa asing, meskipun kosakata tersebut ada padanannya dalam bahasa Indonesia.

Memang tidak ada salahnya, masyarakat Indonesia mengusai banyak bahasa atau multilingual seperti mengusai bahasa Indonesia, bahasa daerah dan bahasa asing. Karena tidak bisa dipungkiri, masyarakat saat ini dituntut mengusai bahasa asing, seperti bahasa Inggris, bahkan malah menjadi sebuah keharusan dan kebutuhan bagi 
sebagian masyarakat tertentu. Walaupun demikian, masyarakat Indonesia tetap harus memperhatikan penggunaan bahasa Indonesia yang tepat, baik, dan benar pada situasisituasi tertentu. Misalnya pada situasi formal. Jangan sampai mencampuradukan bahasa dan tetap menggunakan kaidah bahasa Indonesia yang berlaku.

Berpijak dari pemaparan di atas, bahasa erat sekali dengan penuturnya yaitu suatu masyarakat. Adapun terjadinya hubungan antara bahasa dan masyarakat dapat ditelaah menggunakan salah satu cabang ilmu linguistik makro, yaitu sosiolinguistik. Sosiolinguistik berasal dari kata "Sosial" yang berarti berekanaan dengan masyarakat dan "Linguistik" artinya telaah bahasa. Jadi, sosiolinguistik adalah ilmu yang menelaah tentang bahasa yang berkaitan dengan kondisi kemasyarakatan.

Sosiolinguistik tidak berfokus pada struktur dari sebuah bahasa, tetapi berfokus bagaimana bahasa tersebut digunakan dalam konteks masyarakat beserta budayanya. Salah satu kajian konsentrasi dalam sosiolinguistik, yaitu campur kode atau code mixing. Campur kode merupakan penggunakan dua unsur bahasa atau lebih dalam satu masyarakat tutur. Kode utama memiliki fungsinya sendiri, sedangkan kode-kode lain hanya serpihan saja tidak memiliki fungsinya sendiri.

Campur kode selain dapat dilihat langsung dalam bahasa lisan, seperti di tempat-tempat pendidikan, perkantoran, pasar dan dimana saja. Fenomena campur kode juga dapat dilihat dari bahasa tulis baik di media elektronik maupun media cetak. Salah satunya yang penulis amati, yaitu pada akun Instagram @demakhariini. Akun tersebut merupakan akun berita informasi dan berita terkini mengenai Kota Demak, Jawa Tengah dan sekitarnya. Media sosial Instagram akun @ demakhariini merupakan salah satu akun yang cukup populer dan sangat aktif memberitakan informasi terkini tentang kota Demak, Jawa Tengah, dan sekitarnya. Akun Instagram @demakhariini ini dibuat dari tahun 2015 lalu. Per April 2020, akun Instagram @demakhariini memiliki pengikut lebih dari 87.000, dengan 3.500 lebih unggahan baik foto maupun video. Melihat begitu berpengaruhnya akun Instagram@demakhariini sebagai akun 
berita untuk warga Demak dan sekitarnya, campur kode pada berbagai unggahan yang ada di dalam akun tersebut layak untuk dikaji lebih mendalam.

Berpijak dari pemaparan di atas, penulis akan meneliti campur kode pada akun Instagram@demakhariini mulai bulan Juni sampai Desember 2019. Campur kode biasanya digunakan oleh masyarakat bilingual maupun multilingual salah satunya untuk menulis caption pada foto atau video yang diunggah ke Instagram. Berdasarkan pemaparan di atas, dapat ditentukan masalah yang akan dikaji dalam penelitia ini, yaitu bagaimana jenis-jenis campur kode campur kode yang terdapat pada akun Instagram @ demakhariini. Penelitian ini bertujuan untuk mendeskripsikan jenis-jenis dan bentukbentuk campur kode pada akun Instagram @demakhariini. Adapun manfaat dari penelitian ini adalah:

1. Secara teoretis, memberi wawasan dan pengetahuan tentang kajian kebahasaan khususnya karakteristik campur kode pada Instagram serta memberikan sumbangan ilmu di bidang pengetahuan bahasa khususnya campur kode dalam kajian sosiolinguistik.

2. Secara praktis, menambah pengetahuan penulis atau pembaca mengenai penggunaan campur kode terutama pada Instagram dan penelitian ini diharapkan dapat digunakan oleh peneliti lain sebagai tambahan informasi dan dikembangkan sebagai referensi pada penelitian sejenis berikutnya.

\section{B. KAJIAN TEORI}

Sosiolinguistik mengkaji bahasa dan dikaitkan dengan masyarakat, khususnya masyarakat penutur bahasa itu sendiri. Dalam penelitian ini, teori yang menjadi landasan, yaitu sosiolinguistik, campur kode, dan Instagram. Landasan teori ini akan digunakan sebagai dasar dalam proses analisis data dan pembahasan.

Appel (dalam Aslinda dan Syahfyahya, 2014: 6) mengatakan bahwa sosiolinguistik memandang bahasa sebagai sistem komunikasi sosial serta bagian dari masyarakat dan 
kebudayaan tertentu, sedangkan yang dimaksud dengan pemakaian bahasa adalah bentuk interaksi sosial yang terjadi dalam situasi konkret. Dengan demikian, dalam sosiolinguistik, bahasa tidak dilihat secara internal, tetapi dilihat sebagai sarana interaksi atau komunikasi di dalam masyarakat.

Dalam masyarakat terdapat beberapa fenomena sosiolinguistik selain campur kode dan alih kode, juga terdapat register dalam lingkungan tertentu. Register adalah variasi bahasa berdasarkan ranahnya. Register dapat disebut variasi bahasa yang digunakan berdasarkan bidang penggunaan, keformalan, dan media penggunanya. Misalnya, penggunaan bahasa dalam bidang jurnalistik, olahraga, media sosial, radio, dan sebagainya tentu akan berbeda-beda.

Sebelum membahahas apa itu campur kode, ada baiknya terlebih dahulu mengetahui pengertian kode. Kode merupakan ungkapan yang dipakai untuk menggambarkan makna tertentu. Bahasa manusia adalah sejenis kode. Bahasa merupakan kode yang dipakai dalam komunikasi manusia dalam berinteraksi.

Rahardi (2010: 25) kode dapat didefinisikan sebagai sistem tutur yang penerapan unsur bahasa memiliki ciri khas sesuai dengan latar belakang penutur, relasi penutur dengan lawan bicara dan situasi tutur yang ada. Perbedaan latar belakang penutur bersangkutan dengan tingkat pendidikan, maka perbedaannya terletak pada perbendaharaan kata yang akan dipakai. Orang yang berpendidikan akan memilih perbendaharaan kata, baik kata dari bahasa yang dipakai sehari-hari, bahasa yang jarang dipakai, maupun bahasa asing.

Suandi (2014: 140) mengemukakan bahwa, campur kode dapat dibedakan menjadi tiga jenis berdasarkan asal unsur serapannya, yaitu campur kode ke dalam (inner code mixing) adalah jeniscampur kode yang menyerap unsur-unsur bahasa asli yang masih sekerabat. Misalnya, dalam tuturan bahasa Indonesia terdapat di dalamnya unsurunsur, bahasa Sunda, bahasa Jawa, dan bahasa-bahasa daerah lainnya. Campur kode ke luar (outer code mixing) adalah jenis campur kode yang meyerap unsur-unsur bahasa 
asing. Misalnya, gejala campur kode pada pemakaian bahasa Indonesia terdapat sisipan bahasa Inggris, bahasa Belanda, bahasa Arab dan bahasa-bahasa asing lainnya. Dan campur kode campuran (hybrid code mixing) adalah jenis campur kode yang di dalamnya menyerap unsur bahasa asli (bahasa-bahasa daerah) dan bahasa asing. Misalnya, dalam struktur bahasa Indonesia terdapat unsur bahasa Jawa dan unsur bahasa Arab.

Jendra (dalam Suandi, 2014: 141), campur kode diklasifikasikan berdasarkan perangkat kebahasaan, berdasarkan kategori tersebut, campur kode dibedakan menjadi tiga yaitu, campur kode pada tataran klausa, campur kode pada tataran frasa, dan campur kode pada tataran kata.

Dari pemaparan teori di atas, maka pada penelitian ini penulis akan menggunakan teori dari Suandi, karena teori tersebut dinilai lebih lengkap jenisjenisnya dibanding yang lain. Selain itu, juga karena penulis menemukan tiga jenis campur kode yang terdapat pada akun Instagram @demakhariini. Dalam mengklasifikasikan bentuk-bentuk campur kode, penulis juga menggunakan teori dari Jendra (dalam Suandi 2014: 141 ), karena penulis menemukan tiga bentuk-bentuk campur kode.

\section{METODE PENELITIAN}

Penelitian ini menggunakan metode deskriptif kualitatif. Data-data dalam penelitian ini berupa deskripsi, yakni caption atau keterangan pada unggahan foto dan video pada akun Instagram @ demakharini yang di dalamnya terdapat campur kode.

Sumber data dalam penelitian dibedakan menjadi dua berdasarkan sumbernya yaitu, sumber data primer dan sumber data sekunder. Sumber data primer yang digunakan penulis dalam penelitian ini yaitu caption atau keterangan pada unggahan foto dan video pada akun Instagram @ demakharini. Data sekunder diperoleh melalui media perantara yang berupa data pendukung yang bersumber dari berbagai informasi. Pada penelitian ini penulis menggunakan data pendukung, seperti referensi jurnal atau 
skripsi tentang penelitian sejenis, buku-buku linguistik serta internet yang objek keseluruhan datanya berkaitan dengan penggunaan campur kode.

Pada penelitian ini, pengumpulan data menggunakan metode simak, karena untuk memperoleh data tersebut dilakukan dengan menyimak penggunaan bahasa pada akun Instagram @ demakhariini (Mahsun, 2012: 92). Metode simak digunakan untuk menyimak caption atau keterangan dari unggahan foto atau video pada akun Instagram @demakharini. Teknik selanjutnya yang digunakan yaitu teknik catat, dengan menggunakan alat bantu tagkap layar atau screenshot, untuk mempermudah proses penelitian.

Adapun tahap selanjutnya yaitu teknik analisis data, penulis menggunakan metode padan dengan teknik padan translasional, yaitu analisis bahasa yang penentunya dari luar dan tidak menjadi bagian dari bahasa yang bersangkutan (Sudaryanto, 2015: 13). Teknik lanjutan berupa teknik Pilah Unsur Penentu (PUP), hal tersebut digunakan karena alat penentunya berupa bahasa lain. Bahasa lain yang dimaksudkan yaitu diluar dari bahasa yang diteliti, seperti bahasa Inggris, bahasa Jawa, dan bahasa Arab. Pada penelitian ini, penulis meneliti penggunaan struktur bahasa indonesia, adapun alat penentunya berupa bahasa lain seperti bahasa Inggris, bahasa Jawa, dan bahasa Arab.

\section{HASIL PENELITIAN}

Pada penelitian ini penulis berhasil mengumpulkan data berjumlah 88 data. Data tersebut berupa penggunaan kalimat yang di dalamnya terdapat jenis-jenis dan bentuk-bentuk campur kode yang sesuai dengan penelitian penulis. Dari data tersebut, penulis menemukan tiga jenis campur kode, yaitu campur kode ke dalam, campur kode ke luar, dan campur kode campuran. 


\section{Campur Kode ke Dalam}

Campur kode ke dalam adalah jenis campur kode yang menyerap unsurunsur bahasa daerah atau bahasa asli yang masih sekerabat. Misalnya, dalam tuturan bahasa Indonesia terdapat di dalamnya unsur-unsur bahasa Jawa, bahasa Sunda, dan bahasa-bahasa daerah lainnya. Berikut tabel 1 hasil analisis campur kode ke dalam.

Tabel 1

Campur Kode ke Dalam

\begin{tabular}{|l|l|l|l|}
\hline No. & $\begin{array}{l}\text { No. } \\
\text { Data }\end{array}$ & \multicolumn{1}{|c|}{ Data } & \multicolumn{1}{|c|}{$\begin{array}{c}\text { Makna Bahasa } \\
\text { Indonesia }\end{array}$} \\
\hline 01 & 01 & $\begin{array}{l}\text { Survei membuktikan cah nom Demak lebih } \\
\text { banyak memilih belanja di luar Demak ketika } \\
\text { mau lebaran }\end{array}$ & $\begin{array}{l}\text { Cah nom } \\
\text { 'Anak muda' }\end{array}$ \\
\hline 02 & 02 & $\begin{array}{l}\text { Saatnya membuka senyum kembali, berkumpul } \\
\text { dengan saudara-saudara di kampung, membuka } \\
\text { obrolan ringan, atau basa-basi pertanyaan kapan } \\
\text { rabi? Kapan lulus? Kapan meteng? Dan kapan- } \\
\text { kapan }\end{array}$ & $\begin{array}{l}\text { Rabi } \\
\text { 'Nikah' } \\
\text { Meteng }\end{array}$ \\
'Hamil' \\
\hline 03 & 09 & $\begin{array}{l}\text { Terjadi kecelakan truk berisi muatan kardus } \\
\text { glempang di Buyaran arah Demak kota. }\end{array}$ & $\begin{array}{l}\text { Glempang } \\
\text { 'Terguling' }\end{array}$ \\
\hline 04 & 11 & $\begin{array}{l}\text { Apa yang sedulur mau sampaikan ketika } \\
\text { melihat baliho ini? }\end{array}$ & $\begin{array}{l}\text { Sedulur } \\
\text { 'Saudara' }\end{array}$ \\
\hline 05 & 16 & $\begin{array}{l}\text { Warga Desa Bango Demak ramai-ramai } \\
\text { mencari ikan di pinggir jalan pantura yang } \\
\text { sedang dikuras airnya, karena dibutuhkan untuk } \\
\text { mengairi lahan sawah warga yang kering 'di } \\
\text { mongso ketigo'. }\end{array}$ & $\begin{array}{l}\text { Mongso ketigo } \\
\text { 'Musim kemarau' }\end{array}$ \\
\hline 06 & 22 & $\begin{array}{l}\text { Arumanis, biyen pas cilik sopo seng tangisan } \\
\text { jaluk arumanis? Pas gede yo seh golek seng } \\
\text { manis-manis? Ngaturaken sugeng malem } \\
\text { minggu }\end{array}$ & $\begin{array}{l}\text { Manis-manis } \\
\text { Neng besaran tuku kacang tenanan jebul mung rencang } \\
\text { Mari kakak, tumbas kacang }\end{array}$ \\
\hline 07 & 40 & $\begin{array}{l}\text { Mari } \\
\text { (bahasa Indonesia) }\end{array}$ \\
\hline
\end{tabular}

Berdasarkan tabel 1 di atas, fakta kebahasaan tentang campur kode ke dalam berjumlah 21 data. Terdiri dari penggunakan struktur bahasa Indonesia dengan menyerap unsur bahasa Jawa berjumlah 15 data, yaitu (01) cah nom, 
(02) rabi, meteng, (09) glempang, (11) sedulur, (13) omah, grebeg pawon, monggo, (16) mongso ketigo, (34) kresek, (36) songo, (47) mbah, (50) dolan, lur, (60) lur, lur, kidul, (61) ados, (66) yo rapopo, (72) nengdi, dan (77) wineh.

Sedangkan penggunaan struktur bahasa Jawa menyerap unsur bahasa Indonesia berjumlah 6 data, yaitu (22) manis-manis, (40) mari kakak, (41) belakang, (42) nonton, (67) selamat malam, dan (71) main. Ada beberapa kata dan frasa bahasa Jawa dan bahasa Indonesia yang terdapat di dalamnya.

\section{Campur Kode ke Luar}

Campur kode yang meyerap unsur-unsur bahasa asing. Misalnya, gejala campur kode pada pemakaian bahasa Indonesia terdapat sisipan bahasa Inggris, bahasa Belanda, bahasa Arab dan bahasa asing lainnya. Untuk lebih jelas berikut analisisnya pada tabel 2 .

Tabel 2

Campur Kode ke Luar

\begin{tabular}{|l|l|l|l|}
\hline No. & $\begin{array}{l}\text { No. } \\
\text { Data }\end{array}$ & \multicolumn{1}{|c|}{ Data } & \multicolumn{1}{|c|}{$\begin{array}{l}\text { Makna bahasa } \\
\text { Indonesia }\end{array}$} \\
\hline 01 & 03 & $\begin{array}{l}\text { Kondisi Jalan Sultan Fatah Demak kota pada } \\
\text { pukul 22.00 wib sepi karena jalan ditutup, } \\
\text { diberlakukan Car Free Night }\end{array}$ & $\begin{array}{l}\text { Car Free Night } \\
\text { 'Malam bebas } \\
\text { mobil' }\end{array}$ \\
\hline 02 & 04 & $\begin{array}{l}\text { Live Report Arus Balik malam ini oleh Bripda } \\
\text { Nova @ satlantas_polresdemak }\end{array}$ & $\begin{array}{l}\text { Live Report } \\
\text { 'Berita langsung' }\end{array}$ \\
\hline 03 & 07 & $\begin{array}{l}\text { PSD Demak akan bertanding di fase penyisihan } \\
\text { di grup 1 pada tanggal 14 Juli-25 Agustus 2019 } \\
\text { dengan laga home-away mempertemukan } \\
\text { persibangga Purbalingga, persekat Tegal, BR } \\
\text { USM Semarang, persiku Kudus }\end{array}$ & $\begin{array}{l}\text { homay dari rumah' } \\
\text { 'Jauh }\end{array}$ \\
\hline 04 & 08 & $\begin{array}{l}\text { Bupati Demak HM Natsir resmikan layanan } \\
\text { EYE CENTER di RSUD Sunan Kalijaga } \\
\text { dengan bersamaan peringatan hari ulang tahun } \\
\text { RSUD Sunan Kalijaga Ke 70 Tahun }\end{array}$ & $\begin{array}{l}\text { Eye center } \\
\text { 'Pusat mata' }\end{array}$ \\
\hline 05 & 10 & $\begin{array}{l}\text { Skema ganti rugi pembebasan jalan Tol } \\
\text { Semarang-Demak menjadi pilot project } \\
\text { nasional. }\end{array}$ & $\begin{array}{l}\text { Pilot project } \\
\text { Proyek percobaan' }\end{array}$ \\
\hline
\end{tabular}




\begin{tabular}{|c|c|c|c|}
\hline 06 & 14 & $\begin{array}{l}\text { Tempat Pembuangan Akhir (TPA) yang terletak } \\
\text { di desa Candisari, kecamatan Mranggen dinilai, } \\
\text { sudah over. Demikian juga dengan TPA di desa } \\
\text { Kali kondang, kecamatan Demak. }\end{array}$ & $\begin{array}{l}\text { Over } \\
\text { 'Berlebih' }\end{array}$ \\
\hline 07 & 15 & $\begin{array}{l}\text { Berdasarkan data BMKG, wilayah yang telah } \\
\text { mengalami kekeringan, yaitu sejumlah wilayah } \\
\text { di Jawa dan Madura bagian selatan. Sementara } \\
\text { berdasarkan monitoring hari tanpa hujan, } \\
\text { terdapat potensi kekeringan metereologis di } \\
\text { sebagian besar Jawa, Bali, NTT, dan NTB. }\end{array}$ & $\begin{array}{l}\text { Monitoring } \\
\text { 'Pemantauan' }\end{array}$ \\
\hline 08 & 17 & $\begin{array}{l}\text { Damkar Demak bersama DPUPPE Demak } \\
\text { memasang lampu penerangan di depan Kantor } \\
\text { Damkar Demak yang baru, yang beralamat di } \\
\text { Gedung Ex Radio Suara Kota Wali FM } \\
104.8 \mathrm{MHz} \text { Jl. Sultan Fatah No. } 10 \text { Demak, } \\
\text { Jumat pagi 12/07/2019. }\end{array}$ & $\begin{array}{l}\text { Ex } \\
\text { 'Bekas' }\end{array}$ \\
\hline 09 & 18 & $\begin{array}{l}\text { PSD Demak akan mengawali kompetisi Liga } 3 \\
\text { Zona Jateng 2019 dengan menjamu } \\
\text { Persibangga Purbalingga pada Minggu - } 14 \text { Juli } \\
\text { 2019, waktu kickoff 15:15 WIB di Stadion } \\
\text { Pancasila Demak. }\end{array}$ & $\begin{array}{l}\text { Kickoff } \\
\text { 'Memulai } \\
\text { (tendangan)' }\end{array}$ \\
\hline 10 & 20 & $\begin{array}{l}\text { Untuk semua pencari kerja pendaftaran online } \\
\text { dan harus membawa barcode yang sudah di } \\
\text { print sebagai akses masuk lokasi Job Fair }\end{array}$ & $\begin{array}{l}\text { Online } \\
\text { 'Dalam jaringan' } \\
\text { Barcode } \\
\text { 'Kode batang' }\end{array}$ \\
\hline 11 & 21 & $\begin{array}{l}\text { Untuk informasi lebih lanjut silahkan kunjungi } \\
\text { Showroom Nascomo Demak, Marketing kami } \\
\text { siap melayani dengan sepenuh hati. }\end{array}$ & $\begin{array}{l}\text { Showroom } \\
\text { 'Ruang pameran' } \\
\text { Marketing } \\
\text { 'Pemasaran' }\end{array}$ \\
\hline 12 & 25 & $\begin{array}{l}\text { Kebakaran terjadi di lahan sebelah Graha } \\
\text { Sakinah Jalan Lingkar Jogoloyo pada Senin } \\
\text { siang pukul 14:00 WIB. Kejadian ini juga } \\
\text { sempat menganggu kegiatan Job Fair } 2019\end{array}$ & $\begin{array}{l}\text { Job fair } \\
\text { 'Pameran } \\
\text { pekerjaan' }\end{array}$ \\
\hline 13 & 26 & $\begin{array}{l}\text { Mulai hari Kamis sampai Minggu } 4 \text { Agustus } \\
\text { 2019, akan banyak kemeriahan mulai dari stand } \\
\text { kuliner, parade musik, fashion show, lomba } \\
\text { mewarnai, parade rebana dan zippin serta } \\
\text { banyak stand UMKM. }\end{array}$ & $\begin{array}{l}\text { Fashion show } \\
\text { 'Peragaan busana' }\end{array}$ \\
\hline 14 & 27 & $\begin{array}{l}\text { Kunjungi Demak Expo } 2019 \text { dan jangan lupa } \\
\text { ikut Lomba Foto Selfie }\end{array}$ & $\begin{array}{l}\text { Expo } \\
\text { 'Pameran' } \\
\text { Selfie } \\
\text { 'Berswafoto } \\
\text { sendiri' }\end{array}$ \\
\hline
\end{tabular}




\begin{tabular}{|l|l|l|l|}
\hline 15 & 28 & $\begin{array}{l}\text { Event ini diadakan dari tanggal 1-4 Agustus } \\
\text { 2019 di Gedung Pramuka. }\end{array}$ & $\begin{array}{l}\text { Event } \\
\text { 'Acara' }\end{array}$ \\
\hline
\end{tabular}

Berdasakan tabel 2 di atas, fakta kebahasaan mengenai campur kode ke luar yang berjumlah 51 data, terdiri dari campur kode berbahasa Inggris berjumlah 50 dan campur kode berbahasa Arab berjumlah 1 data, yaitu data (30) Majlis Dzikir dan Maulidurrasul yang berupa kata, frasa, dan klausa bahasa Inggris maupun bahasa Arab yang terdapat di dalamnya.

\section{CAMPUR KODE CAMPURAN}

Campur kode campuran adalah kalimat atau klausa menyisipkan unsur dua bahasa lain atau lebih. Misalnya, pada struktur bahasa Indonesia dengan menyisipkan unsur bahasa Jawa dan bahasa Inggris. Untuk lebih jelasnya, berikut tabel 3 tentang campur kode campuran.

Tabel 3

Campur Kode Campuran

\begin{tabular}{|c|c|c|c|}
\hline No. & $\begin{array}{l}\text { No. } \\
\text { Data }\end{array}$ & Data & $\begin{array}{l}\text { Makna bahasa } \\
\text { Indonesia }\end{array}$ \\
\hline 01 & 003 & $\begin{array}{l}\text { Kondisi Jalan Sultan Fatah Demak kota pada } \\
\text { pukul } 22.00 \text { wib sepi karena jalan ditutup, } \\
\text { diberlakukan Car Free Night }\end{array}$ & $\begin{array}{l}\text { Car Free Night } \\
\text { 'Malam bebas mobil' }\end{array}$ \\
\hline 02 & 006 & $\begin{array}{l}\text { Live Report Arus Balik malam ini oleh Bripda } \\
\text { Nova @ satlantas_polresdemak }\end{array}$ & $\begin{array}{l}\text { Live Report } \\
\text { 'Berita langsung' }\end{array}$ \\
\hline 03 & 010 & $\begin{array}{l}\text { PSD Demak akan bertanding di fase penyisihan } \\
\text { di grup } 1 \text { pada tanggal } 14 \text { Juli-25 Agustus } 2019 \\
\text { dengan laga home-away mempertemukan } \\
\text { persibangga Purbalingga, persekat Tegal, BR } \\
\text { USM Semarang, persiku Kudus }\end{array}$ & $\begin{array}{l}\text { home-away } \\
\text { 'Jauh dari rumah' }\end{array}$ \\
\hline 04 & 011 & $\begin{array}{l}\text { Bupati Demak HM Natsir resmikan layanan } \\
\boldsymbol{E Y E} \boldsymbol{C E N T E R} \text { di RSUD Sunan Kalijaga } \\
\text { dengan bersamaan peringatan hari ulang tahun } \\
\text { RSUD Sunan Kalijaga Ke } 70 \text { Tahun }\end{array}$ & $\begin{array}{l}\text { Eye center } \\
\text { 'Pusat mata' }\end{array}$ \\
\hline 05 & 013 & $\begin{array}{l}\text { Skema ganti rugi pembebasan jalan Tol } \\
\text { Semarang-Demak menjadi pilot project } \\
\text { nasional. }\end{array}$ & $\begin{array}{l}\text { Pilot project } \\
\text { 'Proyek percobaan' }\end{array}$ \\
\hline 06 & 018 & $\begin{array}{l}\text { Tempat Pembuangan Akhir (TPA) yang terletak } \\
\text { di desa Candisari, kecamatan Mranggen dinilai, }\end{array}$ & $\begin{array}{l}\text { Over } \\
\text { 'Berlebih' }\end{array}$ \\
\hline
\end{tabular}




\begin{tabular}{|c|c|c|c|}
\hline & & $\begin{array}{l}\text { sudah over. Demikian juga dengan TPA di desa } \\
\text { Kali kondang, kecamatan Demak. }\end{array}$ & \\
\hline 07 & 019 & $\begin{array}{l}\text { Berdasarkan data BMKG, wilayah yang telah } \\
\text { mengalami kekeringan, yaitu sejumlah wilayah } \\
\text { di Jawa dan Madura bagian selatan. Sementara } \\
\text { berdasarkan monitoring hari tanpa hujan, } \\
\text { terdapat potensi kekeringan metereologis di } \\
\text { sebagian besar Jawa, Bali, NTT, dan NTB. }\end{array}$ & $\begin{array}{l}\text { Monitoring } \\
\text { 'Pemantauan' }\end{array}$ \\
\hline 08 & 023 & $\begin{array}{l}\text { Damkar Demak bersama DPUPPE Demak } \\
\text { memasang lampu penerangan di depan Kantor } \\
\text { Damkar Demak yang baru, yang beralamat di } \\
\text { Gedung Ex Radio Suara Kota Wali FM } \\
104.8 \mathrm{MHz} \mathrm{Jl} \text {. Sultan Fatah No. } 10 \text { Demak, } \\
\text { Jumat pagi 12/07/2019. }\end{array}$ & $\begin{array}{l}\text { Ex } \\
\text { 'Bekas' }\end{array}$ \\
\hline 09 & 024 & $\begin{array}{l}\text { PSD Demak akan mengawali kompetisi Liga } 3 \\
\text { Zona Jateng 2019 dengan menjamu } \\
\text { Persibangga Purbalingga pada Minggu - } 14 \text { Juli } \\
\text { 2019, waktu kickoff 15:15 WIB di Stadion } \\
\text { Pancasila Demak. }\end{array}$ & $\begin{array}{l}\text { Kickoff } \\
\text { 'Memulai } \\
\text { (tendangan)' }\end{array}$ \\
\hline 10 & 027 & $\begin{array}{l}\text { Untuk semua pencari kerja pendaftaran online } \\
\text { dan harus membawa barcode yang sudah di } \\
\text { print sebagai akses masuk lokasi Job Fair }\end{array}$ & $\begin{array}{l}\text { Online } \\
\text { 'Dalam jaringan' } \\
\text { Barcode } \\
\text { 'Kode batang' }\end{array}$ \\
\hline 11 & 028 & $\begin{array}{l}\text { Untuk informasi lebih lanjut silahkan kunjungi } \\
\text { Showroom Nascomo Demak, Marketing kami } \\
\text { siap melayani dengan sepenuh hati. }\end{array}$ & $\begin{array}{l}\text { Showroom } \\
\text { 'Ruang pameran' } \\
\text { Marketing } \\
\text { 'Pemasaran' }\end{array}$ \\
\hline 12 & 032 & $\begin{array}{l}\text { Kebakaran terjadi di lahan sebelah Graha } \\
\text { Sakinah Jalan Lingkar Jogoloyo pada Senin } \\
\text { siang pukul 14:00 WIB. Kejadian ini juga } \\
\text { sempat menganggu kegiatan Job Fair } 2019\end{array}$ & $\begin{array}{l}\text { Job fair } \\
\text { 'Pameran pekerjaan' }\end{array}$ \\
\hline 13 & 033 & $\begin{array}{l}\text { Mulai hari Kamis sampai Minggu } 4 \text { Agustus } \\
\text { 2019, akan banyak kemeriahan mulai dari stand } \\
\text { kuliner, parade music, fashion show, lomba } \\
\text { mewarnai, parade rebana dan zippin serta } \\
\text { banyak stand UMKM. }\end{array}$ & $\begin{array}{l}\text { Fashion show } \\
\text { 'Peragaan busana' }\end{array}$ \\
\hline 14 & 034 & $\begin{array}{l}\text { Kunjungi Demak Expo } 2019 \text { dan jangan lupa } \\
\text { ikut Lomba Foto Selfie }\end{array}$ & $\begin{array}{l}\text { Expo } \\
\text { 'Pameran' } \\
\text { Selfie } \\
\text { 'Berswafoto sendiri' }\end{array}$ \\
\hline 15 & 035 & $\begin{array}{l}\text { Event ini diadakan dari tanggal 1-4 Agustus } \\
2019 \text { di Gedung Pramuka. }\end{array}$ & $\begin{array}{l}\text { Event } \\
\text { 'Acara' }\end{array}$ \\
\hline 16 & 036 & $\begin{array}{l}\text { Tabrakan antar muka mobil box grandmax } \\
\text { dengan mobil pribadi Chevrolet Spin. Keadaan }\end{array}$ & $\begin{array}{l}\text { Box } \\
\text { 'Kotak' }\end{array}$ \\
\hline
\end{tabular}




\begin{tabular}{|c|c|c|c|}
\hline & & $\begin{array}{l}\text { mobil box terguling ke kiri, kejadian tersebut } \\
\text { mengakibatkan kemacetan di sekitar area TKP. }\end{array}$ & \\
\hline 17 & 042 & $\begin{array}{l}\text { Pelepasan jalan sehat dilakukan oleh Bupati } \\
\text { Demak H M Natsir dengan mengambil rute } \\
\text { Pendopo Kabupaten Demak sebagai lokasi } \\
\text { Start - Jl. Kyai Palembang - Jl. Pemuda - TMP } \\
\text { Jl, Kyai Singkil - Pertigaan Depag - Kauman - } \\
\text { Finish Pendopo Demak. }\end{array}$ & $\begin{array}{l}\text { Start } \\
\text { 'Mulai' } \\
\text { Finish } \\
\text { 'Selesai' }\end{array}$ \\
\hline 18 & 049 & $\begin{array}{l}\text { Btw, langit sore di Glagah Wangi bagus sekali } \\
\text { ya. Ayo, siapa yang udah pernah ke sini? }\end{array}$ & $\begin{array}{l}\text { By the way } \\
\text { 'Ngomong- } \\
\text { ngomong' }\end{array}$ \\
\hline 19 & 050 & $\begin{array}{l}\text { "Melalui lomba inilah kita akan ubah fenomena } \\
\text { menjadi reduce, reuse, dan recycle". }\end{array}$ & $\begin{array}{l}\text { Reduce } \\
\text { 'Mengurangi' } \\
\text { Reuse } \\
\text { 'Menggunakan } \\
\text { kembali' } \\
\text { Recycle } \\
\text { 'Daur ulang' } \\
\end{array}$ \\
\hline 20 & 056 & $\begin{array}{l}\text { CABEAN CUP 2019: Presale Ticket } \\
\text { Kickoff mulai } 1 \text { September } 2019 \\
\text { Di Lapangan Kendalisodo Desa Cabean }\end{array}$ & $\begin{array}{l}\text { Presale ticket } \\
\text { 'Tiket harga special' }\end{array}$ \\
\hline 21 & 057 & Nyore nyantai... difollow ya @ dolandemak & $\begin{array}{l}\text { Follow } \\
\text { 'Ikuti' }\end{array}$ \\
\hline 22 & 058 & $\begin{array}{l}\text { Di tempatmu mainan ini apa namanya? Di } \\
\text { tempatku namanya lompat tali. } \\
\text { Photo by @mhadisu }\end{array}$ & $\begin{array}{l}\text { Photo by } \\
\text { 'Foto oleh' }\end{array}$ \\
\hline 23 & 059 & $\begin{array}{l}\text { Mari bersama-sama nyalakan SOLIDARITAS } \\
\text { dengan: } \\
\text { Upload fotomu meyalakan lilin ke media } \\
\text { sosialmu, dengan tagar \#dukungpapua } \\
\text { \#kamibersamapapua }\end{array}$ & $\begin{array}{l}\text { Upload } \\
\text { 'Unggah' }\end{array}$ \\
\hline 24 & 061 & $\begin{array}{l}\text { Zainal Abi, Public Relation Manager PT } \\
\text { Pertagas saat dihubungi secara terpisah, } \\
\text { mengklaim sudah menyosialisasikan kegiatan } \\
\text { pembersihan pipa kepada pihak RT dan Kepala } \\
\text { Desa setempat. }\end{array}$ & $\begin{array}{l}\text { Public Relation } \\
\text { Manager } \\
\text { 'Manajer hubungan } \\
\text { masyarakat' }\end{array}$ \\
\hline 25 & 062 & $\begin{array}{l}\text { Masing-masing penampilkan merupakan } \\
\text { delegasi dari seluruh RT di Desa Purwosari, } \\
\text { selain itu terdapat berbagai stand mengelilingi } \\
\text { arena festival ini. }\end{array}$ & $\begin{array}{l}\text { Stand } \\
\text { 'Pendirian', }\end{array}$ \\
\hline 26 & 065 & $\begin{array}{l}\text { Demak juga punya pantai asik loh, pantai } \\
\text { istambul. Istana Tambak Bulusan. Lumayan } \\
\text { buat liburan pas weekend. }\end{array}$ & $\begin{array}{l}\text { Weekend } \\
\text { 'Akhir pekan' }\end{array}$ \\
\hline
\end{tabular}




\begin{tabular}{|c|c|c|c|}
\hline 27 & 066 & $\begin{array}{l}\text { Langsung order GoRide-nya, dapetin } \\
\text { cashbacknya, dan beli voucher hematnya! }\end{array}$ & $\begin{array}{l}\text { Order } \\
\text { 'Pesan' }\end{array}$ \\
\hline 28 & 068 & $\begin{array}{l}\text { Pembangunan Fisik Fly Over di Ganefo } \\
\text { Maranggen segera di mulai Tahun } 2020 .\end{array}$ & $\begin{array}{l}\text { Fly over } \\
\text { 'Jembatan layang' }\end{array}$ \\
\hline 29 & 069 & $\begin{array}{l}\text { TERUPDATE DIPOST TERBARU } \\
\text { Seorang pelajar SMP di Mranggen tidak } \\
\text { diperbolehkan masuk ke kelas lantara belum } \\
\text { mampu melunasi uang seragam dan uang } \\
\text { sumbangan hingga jutaan rupiah. }\end{array}$ & $\begin{array}{l}\text { Update } \\
\text { 'Terkini' } \\
\text { Post } \\
\text { 'kiriman' }\end{array}$ \\
\hline 30 & 073 & $\begin{array}{l}\text { Warga desa Raji, Kedodondong, Rejosari } \\
\text { mengantrekan jeringen, ember, gentong, dan } \\
\text { wadah lainnya unrtuk menadah dropping air } \\
\text { bersih dari BPBD dan PMI kabupaten Demak. }\end{array}$ & $\begin{array}{l}\text { Dropping } \\
\text { 'Penjatuhan' }\end{array}$ \\
\hline 31 & 081 & Yuk @dolandemak, mumpung weekend. & $\begin{array}{l}\text { Weekend } \\
\text { 'Akhir pekan' }\end{array}$ \\
\hline 32 & 083 & $\begin{array}{l}\text { Salah satu spot di Gotik (Gojoyo Cantik) adalah } \\
\text { hutan mangrove, sudah pernah ke wisata ini? }\end{array}$ & $\begin{array}{l}\text { Spot } \\
\text { 'Tempat' }\end{array}$ \\
\hline 33 & 084 & $\begin{array}{l}\text { Setelah hampir dua minggu gak kerja, akhirnya } \\
\text { liat sunrise, sif tiga juga. }\end{array}$ & $\begin{array}{l}\text { Sunrise } \\
\text { 'Matahari terbit' }\end{array}$ \\
\hline 34 & 086 & $\begin{array}{l}\text { Kalian semua diundang untuk merayakan } 2 \text { th } \\
\text { Anniversary @kumpulmusisi demak silahkan } \\
\text { datang ke Reinz Cafe Resto Besok malam } \\
\text { minggu 05 Oktober } 2019 \text { pukul 19:00 sampai } \\
\text { ngantuk }\end{array}$ & $\begin{array}{l}\text { Anniversary } \\
\text { 'Peringatan' }\end{array}$ \\
\hline 35 & 090 & $\begin{array}{l}\text { Ono wayahe mundur alo-alon ono wayahe } \\
\text { gaspol, panas mongso ketigo iso tekan rogo } \\
\text { mudun ning ati, ojo lali tuku skincare neng } \\
\text { pasar Bintoro lur }\end{array}$ & $\begin{array}{l}\text { Skincare } \\
\text { 'Perawatan kulit' }\end{array}$ \\
\hline 36 & 094 & $\begin{array}{l}\text { Keseharian warga Desa Raji Demak dalam } \\
\text { menghadapi kekeringan, kondisi ini juga merata } \\
\text { terjadi di wilayah kabupaten Demak, setiap hari } \\
\text { warga menadah air dari dropping puluhan truk } \\
\text { tangki BPBD Demak. }\end{array}$ & $\begin{array}{l}\text { Dropping } \\
\text { 'Penjatuhan' }\end{array}$ \\
\hline 37 & 098 & $\begin{array}{l}\text { Yang akan menjadi sasaran yaitu: } \\
\text { 1. Pengendara dan pembonceng sepeda } \\
\text { motor wajib gunakan helm SNI } \\
\text { 2. Gunakan sealt belt }\end{array}$ & $\begin{array}{l}\text { Sealt belt } \\
\text { 'Sabuk pengaman' }\end{array}$ \\
\hline 38 & 102 & $\begin{array}{l}\text { Bus Tenaga Listrik Pertama Made In Indonesia } \\
\text { diproduksi di Demak }\end{array}$ & $\begin{array}{l}\text { Made In } \\
\text { 'Dibuat di' }\end{array}$ \\
\hline 39 & 104 & $\begin{array}{l}\text { Siapa yang belum pernah jalan-jalan ke pasar } \\
\text { Krempyeng? Tag temenmu yag belum pernah } \\
\text { ke sini }\end{array}$ & $\begin{array}{l}\text { Tag } \\
\text { 'Tandai' }\end{array}$ \\
\hline
\end{tabular}




\begin{tabular}{|c|c|c|c|}
\hline 40 & 106 & $\begin{array}{l}\text { Ambyar bareng Lord Didi Kempot di Lapangan } \\
\text { Tembiring Demak dalam rangka Sewindu Resa } \\
\text { Lovers } 11 / 11 / 19 \text {. }\end{array}$ & $\begin{array}{l}\text { Lord } \\
\text { 'Raja' } \\
\text { Lovers } \\
\text { 'Pencinta' }\end{array}$ \\
\hline 41 & 108 & $\begin{array}{l}\text { Tanyakan harga sesuai tujuan dan lama } \\
\text { perjalanan anda, setelah fix silahkan anda } \\
\text { booking dengan melakukan pembayaran DP } \\
\text { minimal } 30 \%\end{array}$ & $\begin{array}{l}\text { Fix } \\
\text { 'Ditentukan) } \\
\text { Booking } \\
\text { 'Memesan' }\end{array}$ \\
\hline 42 & 109 & Happy weekend, yuk piknik bareng keluarga & $\begin{array}{l}\text { Happy weekend } \\
\text { 'Selamat berakhir } \\
\text { pekan' }\end{array}$ \\
\hline 43 & 111 & $\begin{array}{l}\text { Mampir sini ya malem mingguannya, jangan } \\
\text { lewatkan event kali ini }\end{array}$ & $\begin{array}{l}\text { Event } \\
\text { 'Acara' }\end{array}$ \\
\hline 44 & 112 & $\begin{array}{l}\text { Ada yang belum pernah ke Taman Kali Tuntang } \\
\text { Lama akhir-akhir ini buat cobain spot selfie } \\
\text { baru? }\end{array}$ & $\begin{array}{l}\text { spot selfie } \\
\text { 'Tempat } \quad \text { swafoto } \\
\text { sendiri' }\end{array}$ \\
\hline 45 & 113 & $\begin{array}{l}\text { Ikuti Cabean Cup Gold Generation khusus } \\
\text { umur di bawah } 11 \text { tahun atau kelahiran } 2008 .\end{array}$ & $\begin{array}{l}\text { Cup Gold } \\
\text { Generation } \\
\text { 'Piala generasi emas' }\end{array}$ \\
\hline 46 & 114 & $\begin{array}{l}\text { Tujuan smart city sebenarnya hanya } \\
\text { mencerdaskan melalui teknologi sementara } \\
\text { tanpa itu masyarakat sudah cerdas atas } \\
\text { pemahaman teknologi, mestinya pemerintah } \\
\text { mengendepankan tata kota, sehingga jika tata } \\
\text { kota terjamin dan jelas maka smart city akan } \\
\text { berjalan dengan sendirinya dengan baik, }\end{array}$ & $\begin{array}{l}\text { Smart city } \\
\text { 'Kota pintar' }\end{array}$ \\
\hline 47 & 115 & $\begin{array}{l}\text { Sebuah mobil Xenia menabrak pembatas jalan } \\
\text { dan terbalik ketika melaju menuju arah } \\
\text { Semarang. Satu orang penumpang sekaligus } \\
\text { sopir mengalami shock, tidak terdapat luka. }\end{array}$ & $\begin{array}{l}\text { Shock } \\
\text { 'Terkejut) }\end{array}$ \\
\hline 48 & 117 & $\begin{array}{l}\text { Semoga TIMNAS asuhan Coach Indra Sjafri } \\
\text { mendapatkan hasil terbaik saat menghadapi } \\
\text { squad Vietnam. }\end{array}$ & $\begin{array}{l}\text { Coach } \\
\text { 'Pelatih' } \\
\text { Squad } \\
\text { (pasukan) }\end{array}$ \\
\hline 49 & 119 & $\begin{array}{l}\text { Selamat pagi, selamat beraktivitas. } \\
\text { Lok: Desa Bungo, Wedung } \\
\text { Photo by @ afifmenying }\end{array}$ & $\begin{array}{l}\text { Photo by } \\
\text { 'Foto oleh' }\end{array}$ \\
\hline 50 & 120 & $\begin{array}{l}\text { Sisa hujan sore ini meyisakan goresan pelagi. } \\
\text { Lok: Sayung } \\
\text { Photo by @ renikusuma01 }\end{array}$ & $\begin{array}{l}\text { Photo by } \\
\text { 'Foto oleh' }\end{array}$ \\
\hline 51 & 121 & $\begin{array}{l}\text { Narasumber: Zidan Muhyidin, S. Sos.I } \\
\text { Juara I Pemuda Pelopor Demak } \\
\text { Free terbuka untuk umum } \\
\text { Bawa tumbler }\end{array}$ & $\begin{array}{l}\text { Free } \\
\text { 'Bebas' } \\
\text { Tumbler } \\
\text { 'Botol } \\
\end{array}$ \\
\hline
\end{tabular}




\begin{tabular}{|c|c|c|c|}
\hline & & & minum' \\
\hline & 128 & $\begin{array}{l}\text { Menjelang Malam Akhir Tahun, Polsek Demka } \\
\text { Kota antisipasi Kembang Api High Explosive }\end{array}$ & $\begin{array}{l}\text { High Explosive } \\
\text { 'Ledakan kekuatan } \\
\text { besar' }\end{array}$ \\
\hline 53 & 129 & $\begin{array}{l}\text { Info rekayasa lalu lintas Car Free Night sekitar } \\
\text { alun-alun Demak }\end{array}$ & $\begin{array}{l}\text { Car Free Night } \\
\text { 'Malam bebas mobil' }\end{array}$ \\
\hline 54 & 130 & $\begin{array}{l}\text { Malam ini mau hangout menyongsong tahun } \\
\text { baru kemana nih? Atau mau menciptakan } \\
\text { kehangatan bersama orang-orang terdekat di } \\
\text { rumah? }\end{array}$ & $\begin{array}{l}\text { Hangout } \\
\text { 'Berkumpul' }\end{array}$ \\
\hline 55 & 014 & $\begin{array}{lrr}\text { Anshitu } & \text { wasma'uu } & \text { waathi'u } \\
\text { rahimakumullah... } & \text { Selamat } & \text { Menunaikan } \\
\text { Ibadah Sholat Jum'at } & & \end{array}$ & $\begin{array}{l}\text { Anshitu wasma'uu } \\
\text { waathi'u } \\
\text { rahimakumullah } \\
\text { 'Maka perhatikan, } \\
\text { dengarkan, dan } \\
\text { taatilah, semoga } \\
\text { Allah memberikan } \\
\text { rahmat kepada kamu } \\
\text { sekalian' }\end{array}$ \\
\hline 2. & 039 & $\begin{array}{l}\text { Innalilahi wa inna ilahi raji'un. Turut berduka } \\
\text { cita atas wafatnya KH Maimoen Zubair di } \\
\text { Makkah pada Selasa (6/8/2019). }\end{array}$ & $\begin{array}{l}\text { Innalilahi wa inna } \\
\text { ilahi raji'un. } \\
\text { 'Sesungguhnya kami } \\
\text { adalah milik Allah } \\
\text { dan kepada-Nyalah } \\
\text { kami kembali' }\end{array}$ \\
\hline 3. & 030 & $\begin{array}{l}\text { Suasana Majlis Dzikir dan Maulidurrasul } \\
\text { SAW di Masjid Agung Demak bersama Al- } \\
\text { Khidmah pada Sabtu malam } 27 \text { Juli } 2019\end{array}$ & $\begin{array}{l}\text { Majlis Dzikir } \\
\text { 'Tempat mengingat } \\
\text { Allah' } \\
\text { Maulidurrasul SAW } \\
\text { 'Memperingati } \\
\text { kelahiran Rasul / } \\
\text { utusan Allah) }\end{array}$ \\
\hline
\end{tabular}

Berdasarkan tabel 3 di atas, fakta kebahasaan mengenai campur kode campuran berjumlah 16 data. Terdiri dari campur kode campuran menyerap unsur bahasa Jawa dan bahasa Inggris berjumlah 14 data, yaitu pada data 05, 06, 12, 19, 24, 30, 31, 33, 37, 53, 57, 58, 69, dan 85. Campur kode campuran menyerap unsur bahasa Inggris dan bahasa Arab berjumlah 1 data, yaitu pada data (35) assalamualaikum, lovers. Dan campur kode campuran menyerap bahasa Jawa, bahasa Inggris, dan bahasa Arab 
berjumlah 1 data, yaitu pada data (73) lur, jamaah, dan lovers. Ada beberapa kata, frasa, dan klausa bahasa Jawa, bahasa Inggris, dan bahasa Arab yang tedapat di dalamnya.

Berdasarkan pembahasan ada 3 tabel di atas, campur kode yang paling banyak ditemukan dalam unggahan pada akun Instagram @ demakhariini adalah campur kode keluar, yakni campur kode keluar, yakni campur kode bahasa Inggris. Faktor yang melatarbelakangi terjadinya campur kode keluar adalah faktor keterbatasan kode bahasa. Faktor ini terjadi karena terkait dengan karakteristik penutur, seperti keterbatasan dalam penguasaan kosakata dalam bahasa Indonesia. Faktor ini terjadi karena seorang penutur memiliki keterbatasan perbendaharaan kosakata dalam bahasa Indonesia sehingga penutur atau penulis pada akun Instagram @demakhariini menggunakan berbagai istilah bahasa Inggris secara dominan sebagai pengganti kosakata bahasa Indonesia.

\section{E. KESIMPULAN}

Berdasarkan analisis jenis-jenis dan bentuk-bentuk campur kode di atas, dapat disimpulkan bahwa yang dominan adalah jenis campur kode ke keluar berjumlah 51 data atau 58\%, yang terdiri dari campur kode berbahasa Inggris berjumlah 50 data, dan berbahasa Arab 1 data. Sedangkan jenis campur kode ke dalam 21 data atau 24\%, terdiri dari campur kode berbahasa Jawa 15, berbahasa Indonesia 6, dan jenis campur kode campuran 16 data atau 18\%, yang terdiri dari campur kode berbahasa Jawa dan berbahasa Inggris 14 data, campur kode berbahasa Inggris dan berbahasa Arab 1 data, dan campur kode berbahasa Jawa, berbahasa Inggris, dan berbahasa Arab bejumlah 1 data. Berdasarkan temuan di atas, campur kode yang paling dominan dalah campur kode keluar, yakni campur kode keluar, tepatnya campur kode bahasa Inggris. Faktor keterbatasan kode bahasa adalah faktor utama terjadinya campur kode keluar tersebut. Adapun faktor ini terjadi karena keterbatasan penutur dalam penguasaan kosakata 
dalam bahasa Indonesia sehingga penutur lebih memilih menggunakan kosakata bahasa Inggris daripada bahas Indonesia atau bahasa daerah, sepeti bahasa Jawa.

\section{F. SARAN}

Penulis menyarankan agar penelitian-penelitian selanjutnya dapat dikembangkan lagi, seperti faktor penyebab terjadinya campur kode dan fungsi dari campur kode tersebut, sehingga bermanfaat bagi pembaca. Penulis berharap penelitian ini selain dapat dijadikan informasi tambahan untuk memperbaiki penggunaan bahasa terutama pada lingkup formal, juga untuk referensi penulis lain, yang ingin mengkaji sosiolinguistik khususnya penelitian campur kode.

\section{DAFTAR PUSTAKA}

Aslinda, dan Leni Syafyahya, 2014, Pengantar Sosiolinguistik. Bandung, PT. Refika Aditama.

Kunjana, Rahardi, 2001, Sosiolinguistik: Kode dan Alih Kode. Yogyakarta, Pustaka Pelajar Offset.

Mahsun, 2012, Metode Penelitian Bahasa, Tahapan Strategi, Metode, dan Tekniknya, Edisi Revisi. (cetakan keenam), Jakarta, PT RajaGrafindo Indonesia.

Suandi, I Nengah, 2014. Sosiolinguistik, Yoyakarta, Graha Ilmu.

Sudaryanto, 2015, Metode dan Aneka Teknik Analisi Bahasa, Yogyakarta, Sanata Dharma University Press.

Wijana, I Putu Dewa, dan Muhammad Rohmadi, 2013, Sosiolinguistik: Kajian Teori dan Analisis, Yogyakarta, Pustaka Pelajar. 